very large amount of interesting information in a small compass.

The reader never feels that the treatment is sketchy, and the student who assimilates the contents of the book will have laid a solid foundation for further study of special fields of colloid chemistry. There are more than a hundred good illustrations.

\section{Chemical Calculations}

By J. S. Long and H. V. Anderson. (International Chemical Series.) Fourth edition. Pp. xii +266. (New York and London: McGraw-Hill Book Co., Inc., 1940.) 11s. 6d.

$7 \mathrm{HE}$ fact that this book has reached a fourth edition in six years indicates that it has achieved popularity, and the contents show that it provides a very sound and interesting course of exercises. Each section has an introductory outline and a brief statement of the underlying theory, and much of the material here presented is supplementary to that found in text-books. The examples for exercise are numerous, well-chosen and in very many cases provided with answers. Although it is stated that answers are "purposely omitted" in come collections of problems, it is not clear that this has any advantage, and these might well be provided in future editions.

The usual topics in an elementary course are well covered and special mention must be made of the chapters on gas analysis, oxidation and reduction, and those parts of physical chemistry which are of importance in chemical analysis (mass action and solubility product). In the sections on ionic equilibrium the limitations to weak electrolytes are not emphasized, and in calculations involving strong electrolytes the fact that complete ionization is assumed and that the simple law of mass action should not be applied to them is not clearly stated. There is no reason why this should not be done even in an elementary course, and these chapters might well be supplemented and revised in future editions.

The intention of the authors to fit the student to encounter the actualities of chemistry is wholly praiseworthy, and it has been very ably implemented in the book. As they say: "chemical calculations serve to develop in the student aptitude in the application of various principles of chemistry under actual working conditions", and since the book can be covered in fifteen weekly periods in the first year, this valuable training should not encroach unduly on other parts of the course.

\section{Gmelins Handbuch der anorganischen Chemie}

Achte völlig neu bearbeitete Auflage. Herausgegeben von der Deutschen Chemischen Gesellschaft. SystemNummer 27 : Magnesium. Teil B, Lief 4 : Schluss der Verbingungen, Technische Darstellung der Magnesiumverbindungen. Pp. 423-550+xx+xviii. (Berlin : Verlag Chemie, G.m.b.H., 1939.) 18.75 gold marks.

THE present part of "Gmelins Handbuch" covers compounds of magnesium with the alkali metals and ammonium and beryllium, and describes technical methods of manufacturing the oxide, hydroxide, carbonate, chloride and sulphate of the metal. Magnesium oxide and hydroxide are manufactured chiefly from magnesite, although numerous processes have been adopted for utilizing dolomite. The temperature at which the oxide sinters is very high, but can be lowered appreciably by the addition of ferric oxide. The hot material is sprinkled with water to hydrate any calcined limestone, dolomite or caustic magnesia, which react much more easily than sintered magnesia to form a dust which is easily separated.

Much work has been done on the preparation of anhydrous magnesium chloride for the electrolytic extraction of the metal. As is well known, dehydration of the hexahydrate is accompanied by hydroly sis, so that the salt has to be heated in the presence of hydrogen chloride, which causes rapid corrosion of the vessels from $325^{\circ} \mathrm{C}$. upwards, but it has been found possible to raise the temperature to $450^{\circ} \mathrm{C}$. and thereby greatly accelerate dehydration by rigorously excluding air. Other methods used for dehydration of the chloride involve either electrolytic decomposition of the water alone, or the formation at low temperatures of a hexamine which can be dried at $300^{\circ} \mathrm{C}$., or the conversion of the oxide direct to chloride.

\section{Introduction to Carbohydrate Biochemistry}

By Dr. D. J. Bell. Pp. viii + 112. (London : University Tutorial Press, Ltd., 1940.) 3s. $6 d$.

TO class of organic compounds surpasses the 1 carbohydrates in interest. Sir Frederick Hopkins speaks of the intellectual thrills induced by the progress of the work of Emil Fischer in particular: since then the development has been to some extent in Great Britain. Almost every worker in biochemistry, using the term in its widest significance, has to know something about the sugars and to master their structural formulæ. It is for these that the present book is provided, and its ordered assembly of formulæ drawn and printed with praiseworthy clarity will go far to make what is in reality difficult appear easy.

The subject-matter is highly concentrated, but the author has the knack of putting the essentials into the fewest words. After describing the sugars themselves he discusses the liberation of energy during fermentation, metabolism in muscle, uronic acids, glycosides, nucleotides in particular. Sufficient references are given to the literature.

The book forms a notable contribution to any library which no biochemist can be without.

\section{Principles of Animal Biology}

By Prof. Lancelot Hogben. Second edition, revised. Pp. 415. (London: George Allen and Unwin, Ltd., 1940.) $7 \dot{s} .6 d$. net.

DROF. HOGBEN'S text-book on animal biology was first published in 1930 and later went out of print. The present edition planned on the same lines as the original, although the pattern has been improved by the adequate revision of the whole book 